\title{
Trade and Income Distribution: A Study of Latin American \& Asian Developing Economies
}

* Rashmi Ahuja

\begin{abstract}
https://dx.doi.org/10.33601/effulgence.rdias/v14/i1/2016/32-38

The changes in income inequality have been observed in developing economies which are rapidly opening up to international trade and foreign capital inflows in the past few decades. This paper examines the impact of increased trade openness on withincountry income inequality in Latin A merican and Asian developing economies over the period 2000-2012.The analysis finds the experience of Latin American developing economies different from that of Asian developing economies. Not only increased trade openness but also stronger economic growth and education contribute to declining income inequality in Latin American developing economies over the period 2000-2012. However, in Asian developing economies, the income inequality increases with increased trade openness up to certain point and after that it starts declining. The findings also suggest that the impact of trade on inequality in Asian developing economies depends on the level of education in these economies. The analysis also finds that the impact of trade and foreign capital inflows on income inequality is different in developing economies within the two sub-regions in Latin America.
\end{abstract}

Rukmini Devi Institute of Advanced Studies

E-mail : effulgence@rdias.ac.in, Website : www.rdias.ac.in

http://effulgence.rdias.ac.in/user/default.aspx

Key Words: Trade and Income, Foreign Capital Inflows, Trade openness, Developing Countries.

\section{INTRODUCTION}

$\mathrm{I}^{\mathrm{n}}$ $n$ the past few decades, the developing economies are rapidly opening up to international trade and foreign capital inflows. This increased economic openness has helped these economies in not only achieving higher economic growth but also provides them access to new technology, knowledge and skills. However, at the same time, questions have been raised in the literature regarding the distributional impacts of such increased economic openness in these economies. It is observed that the period of increasing economic integration coincides with the changes in income inequality which points out the presence of likely link between economic openness and income inequality in these economies. The increased income inequality can have important implications on not only welfare but can also limit the potential for growth in a country. So, it becomes really important to understand the linkages, if any, between income inequality, international trade and foreign capital inflows in these economies.
Rodrik(1997) pointed out that reduced barriers in trade and investment make visible the differences between the groups that can cross international borders (directly or indirectly) and those who can't. He argued that due to greater openness, the elasticity of demand for unskilled, semi-skilled and most middle managers is increased i.e. they can be easily substituted by the services of the other people across national boundaries. Also, the bargaining position of these workers, which influences their demand for increase in wages and other benefits from the companies, will be weakened. Hence, the inequality between these two groups of workers will worsen as a result of greater economic openness.

The dramatic changes in the trade policies have been observed in both Asian and Latin American developing economies in the past few decades. In most of these economies, there has been shift in the trade policies away from trade protectionism to trade liberalization. It is observed that inequality has increased in Latin American economies during this period of trade reforms i.e. during 1980's and 1990's. However, looking at the 
pattern of inequality over the period 2000-2012, the Latin American economies have started witnessing a declining trend in the income inequality (Figure 1). The Asian developing economies follow different patterns of income inequality in the past few decades. For instance, in india, there is a stagnation in inequality till 1990's and then from 1990's the inequality increase and then again in 2000's it decreases. In China, inequality increases from the eighties to the mid-2000's and after that its starts decreasing. In Thailand, the inequality increase up to the mid-1980's and after that it started declining. It is observed that out of eight selected Asian developing economies, inequality has declined in four economies during the period 2000-2012 (Figure 2). There have also been wider studies in the literature that suggests and further examined the relationship between increasing trade liberalization and income inequality in developing economies. Hence, it is interesting to examine how trade liberalization affects the income inequality in these economies over the period 2000-2012.

Figure 1: Percent change in Gini coefficient of net income, 2000-2012 in Fifteen Latin American Developing Economies

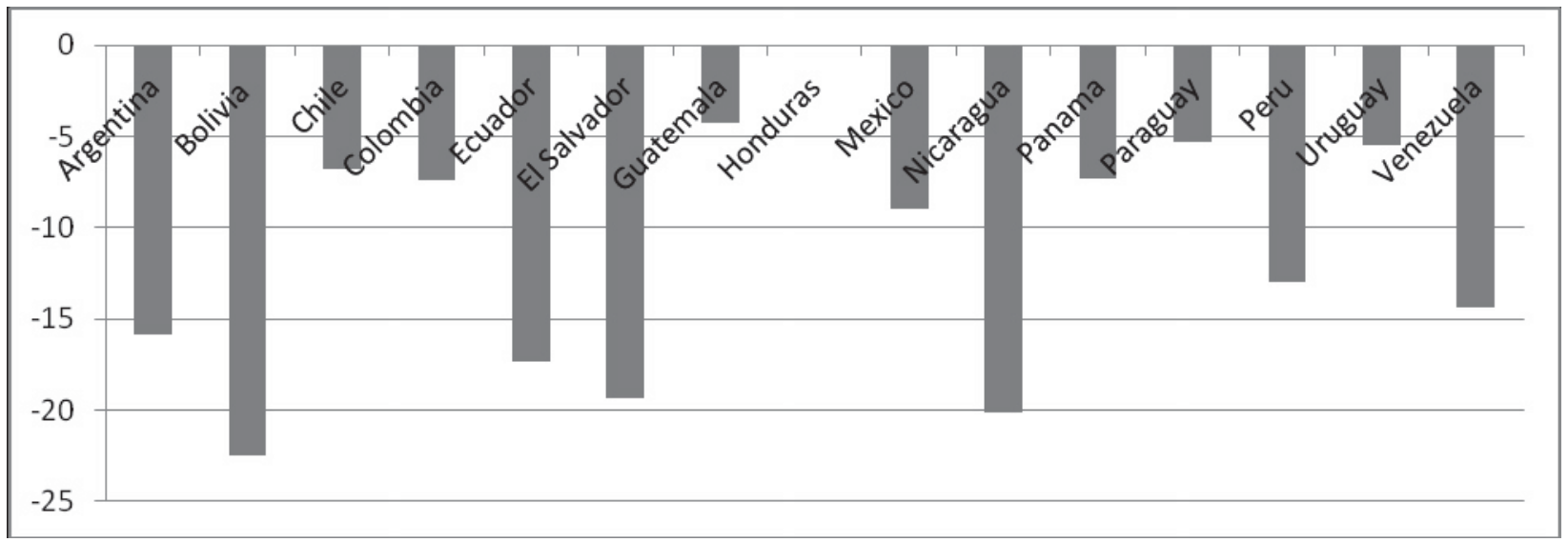

Source: constructed by author using data from SWIID Database

Figure 2: Percent change in Gini coefficient of net income, 2000-2012 in Eight Asian Developing Economies

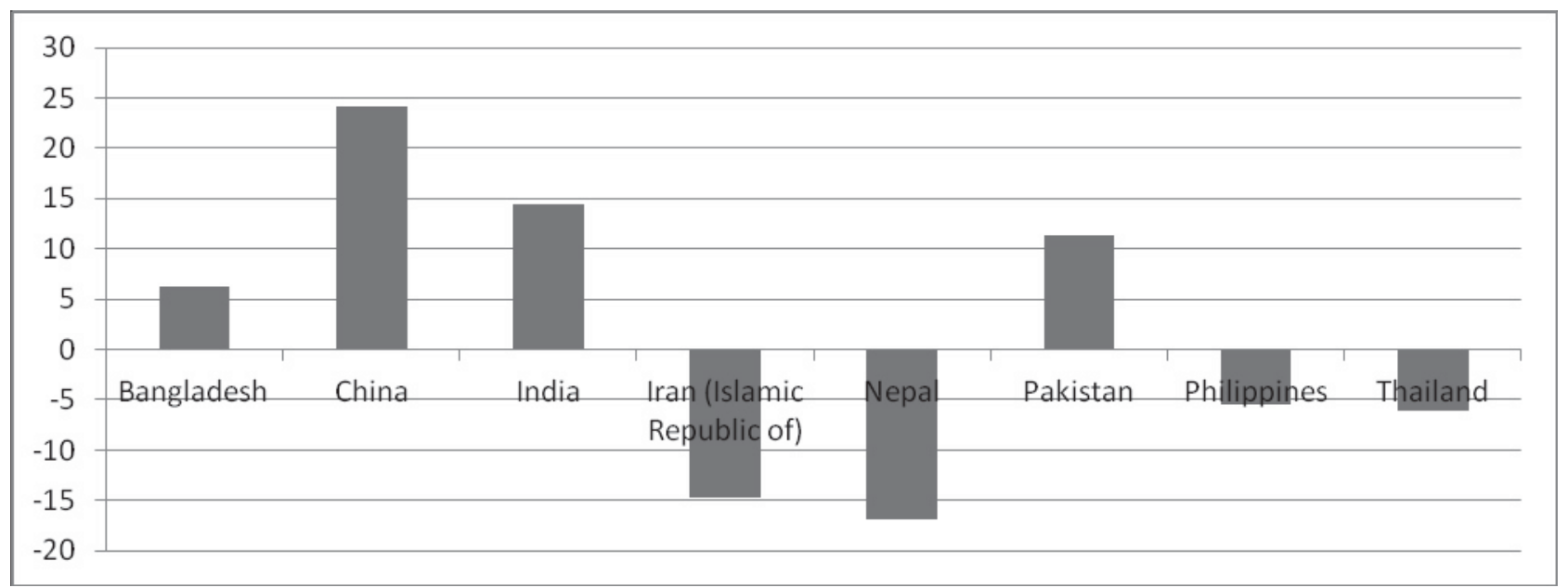

Source: constructed by author using data from SWIID Database 
The rest of the paper is organized as follows. In section two, the objectives of the paper are stated. In section three, a brief literature review is presented. After that, the empirical model is described. In the fifth section, the findings are reported while the last section concludes.

\section{OBJECTIVES}

The aim of this paper is to examine the distributional consequences of increased trade openness in 23 Asian and Latin American developing economies over the period 2000-2012. To achieve the above objective, the static panel data estimation techniques are used. This study contributes to the literature by exploring the possibility of curvilinear relationship between trade openness and income inequality in these economies. It also examined how the experiences of impact of trade on income inequality in Latin American developing economies differs from that of Asian developing economies over the period 2000-2012. Besides that, it further examined whether the impact of increased trade openness on income distribution differs between the countries from two different sub regions in Latin America- Mexico \& Central America and South America.

\section{LITERATURE REVIEW}

The issue of income inequality has received considerable attention in the economic literature in the last three decades. The inequality is not only an outcome of growth but also a determinant of growth. The concern has also been expressed with regard to increased income inequality in some of the developing economies which are rapidly opening up to international trade and foreign capital inflows. The principle reference point for studying the linkages between international trade and income inequality is the Heckscher-Ohlin-Samuelson (HOS) model and the Stolper-Samuelson theorem. According to Stolper Samuelson (1941) theorem, the trade openness of a country will benefit the abundant factor in the country. This means that, in case of developing economies where unskilled labor is the abundant factor, as trade liberalizes, the income of unskilled labor will increase which further decreases income inequality. However, opposite is the case in developed countries i.e. it is the skilled labor that will benefit from the trade liberalization.
Another notable point in the theoretical trade literature is the distinction between the Heckscher-Ohlin ( $\mathrm{H}-\mathrm{O})$ model and the specific factor model. The specific factor model will assume a factor to be specific to a sector and hence can be used in that sector only whereas $\mathrm{H}-\mathrm{O}$ model assume the factors can move between the different sectors within the country. The kind of model can have important distributional implications because two models differ in the way resources are redistributed once the trade takes place.

There also exists a vast empirical literature that examines the impact of trade on inequality in developing economies. However, the findings of these empirical studies are found to be different from theoretical framework. Gourdon (2011) finds that trade liberalization increases inequality in countries that are relatively well endowed in capital. He also breakdown the unskilled labor into non-educated and primary educated categories and further finds that trade liberalization increases inequality in non-educated abundant countries while it decreases inequality in primary educated abundant countries. Meschi and Vivarelli (2009) find that trade with high income countries worsens income inequality in developing countries, especially in middle-income countries, because of technological differentials and skill-biased nature of new technologies. Goldberg and Pavnick $(2004,2007)$ show that trade has a distributional consequences in developing economies and they find that trade does not benefit the unskilled labor as predicted in the trade theories. Davis (1996) in his study concluded that the direct global comparison of factor abundance is irrelevant for the Stolper Samuelson effects of trade liberalization. He said that it is the local factor abundance relative to its own cone of diversification which is important. Davis and Mishra (2007) argued that "Stolper-Samuelson is dead" and it is dangerous to conclude that trade increases the unskilled wages which is the abundant factor in developing economies based on trade theories. They argue that Stolper-Samuelson theorem holds only when all the countries produces all goods and imported goods and domestically produced goods are close substitutes.

Over the years, the shortcomings of the theoretical frameworks used to examine trade-inequality linkages are recognized gradually and hence, the new 
explanations have been added to the basic framework in the trade literature. Trade in tasks or Offshoring suggested by Feenstra and Hanson (1996), Innovation or Research \& Development (see Dinopoulos and Segerstrom (1999)), Heterogeneous firm literature introduced by Melitz (2003), Product Quality Upgrading (see Verhoogen (2008)) etc. are some of the explanations being sought in the trade literature to explain the discrepancies in the empirical and theoretical findings on trade-inequality linkages in the economies. A detailed literature survey of all the theoretical and empirical works on testing trade-inequality linkages can be found in Harrison, McLaren and Mcmillan (2010).

\section{DATA \& ECONOMETRIC METHODOLOGY}

A panel dataset is constructed for 23 developing economies over the period 2000-2012. The sample consists of 15 Latin American and 8 Asian developing economies ${ }^{2}$. To investigate the impact of increasing trade openness on income inequality, the following panel data model is formulated where $\mathrm{i}$ denote countries and $\mathrm{t}$ denotes year:-

$$
Y_{i t}=\beta_{0}+\beta_{1} \text { Trade_op } p_{i t}+\eta X_{i t}+\alpha_{i}+\mu_{i t}
$$

Where $\mathrm{Y}_{\mathrm{it}}$ is the dependent variable, $\mathrm{X}_{\mathrm{it}}$ is the control variables, $a_{i}$ is the time-constant intercept term to capture country specific effects that are time invariant and $\mathrm{m}_{\mathrm{it}}$ is the error disturbance term.

In each regression, the dependent variable is Gini coefficient. The explanatory variable is the standard trade openness indicator measured by the total exports and imports of goods and services as a percentage of GDP. The following are the elements of the control variables used in the study:-

Firstly, the variable GDP per capita is included in the regression as inequality is believed to be dependent on the level of development of the country. Second, foreign capital inflows stock as a percentage of GDP is also included as one of the control variable as there exists vast literature which shows that foreign capital inflows also affect the income inequality. The other two control variables added are based on the past empirical literature: Education and Inflation. The secondary school enrollment as a percentage of gross is used to proxy the amount of human capital available in the country. It is expected that as the secondary school enrollment increases, the income inequality should decrease. The inflation can also impact the income distribution within an economy as it is believed that it is the poor who gets more affected due to increase in inflation.

The data for Gini coefficient is obtained from SWIID version 5.0 Database. The data for trade and foreign capital inflows is obtained from UNCTAD trade and FDI statistics. The data of all other variables is obtained from the World Development indicators (2014) complied by the World Bank. Initially, three main approaches for panel data regression analysis are considered i.e. pooled OLS, Random effect and fixed effect model. Breusch and Pagan Lagrange Multiplier test (1980) $(1 \mathrm{~m})$ is conducted in order to confirm the existence of country specific factors in the model. If the null hypothesis of no country effects is rejected, the study will proceed with the Fixed and random effect estimations. Finally, in order to decide between the random and fixed effect models, the classic Hausman specification test is used. The problems of heteroscedasticity and serial correlations are also accounted in the model used in this study and accordingly the corrected standard errors are reported in the results.

\section{RESULTS}

The findings of the F-test and Hausman test, for a sample of 23 Developing economies, suggest that there exists country specific fixed effects and fixed effect model is found to be more appropriate in all cases except in case of Mexico and Central America region regressions.

From the findings of the study in Table 1, it can be observed that trade and foreign capital inflows does not have significant impact on income inequality in our

\footnotetext{
${ }^{2}$ The countries considered in the sample are :Argentina, Bolivia, Chile, Colombia, Ecuador, Guatemala, Pakistan, El-Salvador, Mexico, Honduras, Nicargua, Panama, Paraguay, Peru, Uruguay, Venezuala, Bangladesh, China, India, Iran, Nepal, Phillipines, Thailand.
} 
sample of 23 developing economies over the period 2000-2012. However, level of development of country is found to be highly significant in reducing the income inequality in these developing economies.

When the whole sample of 23 developing economies is divided into two sub-samples of 8 Asian and 15 Latin American developing economies (Table 2 ), then it is find that increased trade openness has a significant positive impact on the income distribution in the sample of Latin American countries over the period 2000-2012 whereas it deteriorates income inequality in Asian developing economies. In order to test for the curvilinear relationship of trade with inequality, square term of trade openness is added to the baseline model for

Table 1 : Regression Results for whole sample of 23 Asian and Latin American Developing Economies

\begin{tabular}{|l|l|l|}
\hline Dependent Variables : Gini coefficient & \multicolumn{2}{|l|}{} \\
\hline Indep . Variables & Model(1) & Model(2) \\
\hline Trade & -.0220155 & -.0177581 \\
& $(-0.49)$ & $-0.21)$ \\
\hline Trade $^{2}$ & ------- & -.0000291 \\
& & $(-0.07)$ \\
\hline FDI & .0713413 & .0714987 \\
& $(1.15)$ & $(1.16)$ \\
\hline GDPP & $-.001759^{* * *}$ & $-.001753^{* * *}$ \\
& $(-4.58)$ & $(-4.37)$ \\
\hline Educ & -.0809073 & -.0810769 \\
& $(-1.65)$ & $(-1.67)$ \\
\hline Infln & -.0053895 & -.0055506 \\
& $(-0.27)$ & $(-0.28)$ \\
\hline No. of observ & 228 & 228 \\
\hline
\end{tabular}

(Note: t-statistics are reported in brackets. $* * * * * / *$ denotes the statistical significance at $1 \%, 5 \%$ and $10 \%$ respectively)

Table 2 : Regression Results for individual samples of Latin American and Asian Developing countries

\begin{tabular}{|c|c|c|c|c|}
\hline \multicolumn{5}{|c|}{ Dependent Variable : Gini } \\
\hline \multirow[b]{2}{*}{ Indep. Variables } & \multicolumn{2}{|c|}{ Mexico and Central America } & \multicolumn{2}{|l|}{ South America } \\
\hline & $\operatorname{Model}(9)$ & Model(10) & Model (11) & $\operatorname{Model}(12)$ \\
\hline Trade & $\begin{array}{l}.0779415^{* * *} \\
(2.83)\end{array}$ & $\begin{array}{l}-.0996308 \\
(-0.71)\end{array}$ & $\begin{array}{l}-.0786127^{* *} \\
(-2.37)\end{array}$ & $\begin{array}{l}-.0125898 \\
(-0.16)\end{array}$ \\
\hline Trade $^{2}$ & -------- & $\begin{array}{l}.0008561 \\
(1.29)\end{array}$ & ----------- & $\begin{array}{l}-.0005827 \\
(-1.12)\end{array}$ \\
\hline FDI & $\begin{array}{l}-.0809057^{*} \\
(-1.76)\end{array}$ & $\begin{array}{l}-.0789734^{*} \\
(-1.67)\end{array}$ & $\begin{array}{l}.1263174^{* * *} \\
(3.65)\end{array}$ & $\begin{array}{l}.1212516^{* *} \\
(3.34)\end{array}$ \\
\hline GDPP & $\begin{array}{l}.0003704 \\
(1.37)\end{array}$ & $\begin{array}{l}.0000375 \\
(0.11)\end{array}$ & $\begin{array}{l}-.0017548^{* * *} \\
(-6.05)\end{array}$ & $\begin{array}{l}-.0018009^{* * *} \\
(-6.22)\end{array}$ \\
\hline Educ & $\begin{array}{l}-.164277^{* * *} \\
(-3.41)\end{array}$ & $\begin{array}{l}-.1151021^{*} \\
(-1.69)\end{array}$ & $\begin{array}{l}-.0823918^{* *} \\
(-2.88)\end{array}$ & $\begin{array}{l}-.0823148^{* *} \\
(-2.81)\end{array}$ \\
\hline Infln & $\begin{array}{l}.0694952 \\
(0.54)\end{array}$ & $\begin{array}{l}.0586892 \\
(0.49)\end{array}$ & $\begin{array}{l}-.0216496 \\
(-1.04)\end{array}$ & $\begin{array}{l}-.0287628 \\
(-1.41)\end{array}$ \\
\hline No. of observ. & 62 & 62 & 105 & 105 \\
\hline
\end{tabular}

(Note: t-statistics are reported in brackets. $* * * * * / *$ denotes the statistical significance at $1 \%, 5 \%$ and $10 \%$ respectively) 
both the sub samples. It is find that trade openness follows a curvilinear relationship with inequality in Asian developing economies i.e. inequality first increases with trade openness until a threshold level is reached and further it decreases while no such relationship is confirmed in the case of Latin American developing economies. The positive and significant interaction term in Asian developing economies shows that the impact of increased trade openness on income inequality depends on the level of human capital in these economies. It implies that in more educated Asian developing economies, lesser will be the negative impact of increasing trade openness on income inequality.

The findings also suggests the highly significant inequality decreasing impact of level of development and human capital in the Latin American developing economies over the period 2000-2012.This makes Latin American economies more interesting case to be studied further. Hence, the sample of 15 Latin American developing economies is further subdivided into two samples based on two different sub regions in Latin America i.e. 1) Mexico and Central America and 2) South America. In the next step, the individual regressions on both these samples are run. The findings from these regressions (Table 3) suggest that increased trade openness deteriorates income inequality in economies in Mexico and Central America region while it reduces income inequality in economies in South America. However, when the square term of trade openness is added to the regression, the impact of trade openness becomes insignificant in economies in both the sub-regions. The foreign capital inflows improve income inequality in economies from Mexico and Central America region while it increases income inequality in economies from South America region. The findings also confirm the positive impact of education on income inequality in economies from both the regions within Latin America.

Table 3 : Regression results for countries in two sub regions within Latin America

\begin{tabular}{|c|c|c|c|c|c|c|}
\hline \multicolumn{7}{|c|}{ Dependent variable: Gini coefficient } \\
\hline \multirow[b]{2}{*}{ Indep. Variables } & \multicolumn{3}{|c|}{ Latin American sample } & \multicolumn{3}{|c|}{ Asian Developing economies Sample } \\
\hline & Model (3) & Model(4) & Model(5) & Model(6) & Model(7) & Model(8) \\
\hline Trade & $\begin{array}{l}.0848724^{*} \\
(-1.94)\end{array}$ & $\begin{array}{l}.1338087^{*} \\
(-1.78)\end{array}$ & $\begin{array}{l}-.1583087 \\
(-1.53)\end{array}$ & $\begin{array}{l}.1190503^{\text {** }} \\
(2.40)\end{array}$ & $\begin{array}{l}.2770176^{* * *} \\
(3.70)\end{array}$ & $\begin{array}{l}.279366^{* * *} \\
(3.63)\end{array}$ \\
\hline Trade $^{2}$ & 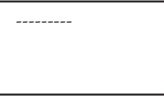 & $.0003343(0.99)$ & 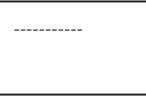 & 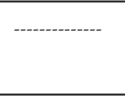 & $\begin{array}{l}-.0010685^{* *} \\
(-2.39)\end{array}$ & 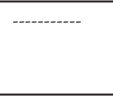 \\
\hline FDI & $.0707967(1.36)$ & $\begin{array}{l}.068896 \\
(1.38)\end{array}$ & $\begin{array}{l}.0678117 \\
(1.27) \\
\end{array}$ & $\begin{array}{l}-.2073437 \\
(-1.26)\end{array}$ & $\begin{array}{l}-.2021449 \\
(-1.38)\end{array}$ & $\begin{array}{l}-.1140227 \\
(-0.61)\end{array}$ \\
\hline GDPP & $\begin{array}{l}-.0014427^{* * *} \\
(-3.92)\end{array}$ & $\begin{array}{l}-.001518^{* * *} \\
(-4.99)\end{array}$ & $\begin{array}{l}-.0015237^{* * *} \\
(-4.80)\end{array}$ & $\begin{array}{l}-.0021143 \\
(-0.63)\end{array}$ & $\begin{array}{l}-.002378 \\
(-0.72)\end{array}$ & $\begin{array}{l}-.0016326 \\
(-0.43)\end{array}$ \\
\hline Educ & $\begin{array}{l}-.1298997^{* * *} \\
(-3.11)\end{array}$ & $\begin{array}{l}-.1284692^{* * *} \\
(-3.08)\end{array}$ & $\begin{array}{l}-.1793162 * * \\
(-2.33)\end{array}$ & $\begin{array}{l}.0924415 \\
(0.53)\end{array}$ & $\begin{array}{l}.0941795 \\
(0.56)\end{array}$ & $\begin{array}{l}.210714 \\
(1.30)\end{array}$ \\
\hline Infln & $\begin{array}{l}-0232489 \\
(-1.37)\end{array}$ & $\begin{array}{l}-0216472 \\
(-1.06)\end{array}$ & $\begin{array}{l}.0263578 \\
(-1.54) \\
\end{array}$ & $\begin{array}{l}.0238649 \\
(0.99) \\
\end{array}$ & $\begin{array}{l}.0184309 \\
(0.86) \\
\end{array}$ & $\begin{array}{l}.0048846 \\
(0.20)\end{array}$ \\
\hline Trade_Educ & --n--- & 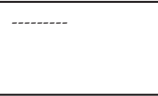 & $\begin{array}{l}.0009587 \\
(0.76)\end{array}$ & -.--o-- & $+\ldots$ & $\begin{array}{l}-.0023119^{*} \\
(-2.01)\end{array}$ \\
\hline No. of observ. & 167 & 167 & 167 & 61 & 61 & 61 \\
\hline
\end{tabular}

\section{CONCLUSION}

Our analysis of the experience of twenty three Latin American and Asian developing countries provides some insights into the distributional consequences of greater trade openness during the period 2000-2012. The static panel data estimation techniques are used to estimate the impact of greater trade openness on within-country income inequality in these developing economies. The possibility of curvilinear relationship between trade openness and income inequality is also explored in these economies. Further, the study examined how these 
trade-inequality linkages differ between the Latin American and Asian developing economies and also between the economies within the two sub-regions in Latin America.

The findings suggest that only level of economic development has significant and inequality reducing impact in our sample of 23 developing economies. Once this whole sample is divided into individual samples of Asian and Latin American developing economies, the results of our study suggests that over the period 20002012, increased trade openness has a significant positive impact on income inequality in Latin American developing countries whereas it deteriorates income inequality in Asian developing economies. Moreover, the curvilinear relationship of trade openness and inequality is confirmed in case of only Asian developing economies. Also, it is interesting to note that in more educated Asian developing economies, the negative impact of increasing trade openness on income inequality will be lesser. In case of Latin American developing economies, level of development and human capital have highly significant inequality decreasing impact over the period 2000-2012. It is also find that the impact of increasing trade as well as foreign capital inflows on income inequality is different in the economies in the two sub regions in Latin America.

It can be concluded from this study that the experience of inequality in Latin American developing economies is different from that of Asian developing economies over the chosen period of study. Not only trade but also stronger GDP growth and education have contributed to the declining income inequality in Latin American developing economies over the period 2000-2012.

\section{REFERENCES}

1) Davis, D. R. (1996), "Trade liberalization and income distribution”, NBER Working Paper, No. 5693, Cambridge, Massachusetts, National Bureau of Economic Research.

2) Davis, D. R., \& Mishra, P. (2007), "StolperSamuelson is dead: And other crimes of both theory and data", Globalization and poverty (pp. 87-108). University of Chicago Press.

3) Dinopoulos, E. \& Segerstrom P. S. (1999), “A Schumpeterian Model of Protection and Relative
Wages”, American Economic Review 89(3): 450-472.

4) Feenstra, R. C., \& Hanson, G. (1996), "Globalization, outsourcing, and wage inequality", American Economic Review, 86(2), 240-245.

5) Goldberg, P. and Pavcnik, N. (2004), "Trade, inequality, and poverty: What do we know? : Evidence from recent trade liberalization episodes in Developing countries", NBER Working Paper No. 10593, National Bureau of Economic Research.

6) Goldberg, P. and Pavcnik, N.(2007),"Distributional effects of globalization in developing countries", NBER Working Paper No. 12885, National Bureau of Economic Research.

7) Gourdon, J. (2011), "Trade and Wage Inequality in Developing Countries: South-South Trade Matters”, International Review of Economics, Vol. 58(4), pp 359-383.

8) Harrison, A., \& Hanson, G. (1999),"Who gains from trade reform? Some remaining puzzles", Journal of development Economics, 59(1), 125-154.

9) Harrison, A., McLaren, J., \& McMillan, M. S. (2010), "Recent findings on trade and inequality", NBER Working Paper No. 16425, National Bureau of Economic Research.

10) Meschi, E. and Vivarelli, M. (2009), "Trade and income inequality in developing countries", World Development, 37(2), 287-302.

11) Melitz, M. (2003),"The impact of trade on intra industry reallocations and aggregate industry productivity", Econometrica, 71(6), 1695-1725.

12) Rodrik, D. (1997), "Has Globalisation gone too far?”, Institute for International Economics, Washington DC.

13) Stolper, F. W., \& Samuelson, P. A. (1941), "Protection and real wages", Review of Economic Studies, 9, 58-73.

14) Verhoogen, E. (2008), "Trade, Quality Upgrading, and Wage Inequality in the Mexican Manufacturing Sector”, The Quarterly Journal of Economics, MIT Press, 123(2), 489-530. 